UCRL-ID-133530

\title{
Tracing and Age-Dating Injected Groundwater of the West Basin Barrier Project, Los Angeles, California
}

\author{
M.L. Davisson \\ G.F. Eaton \\ G.B. Hudson \\ C. Koester
}

March 26, 1999

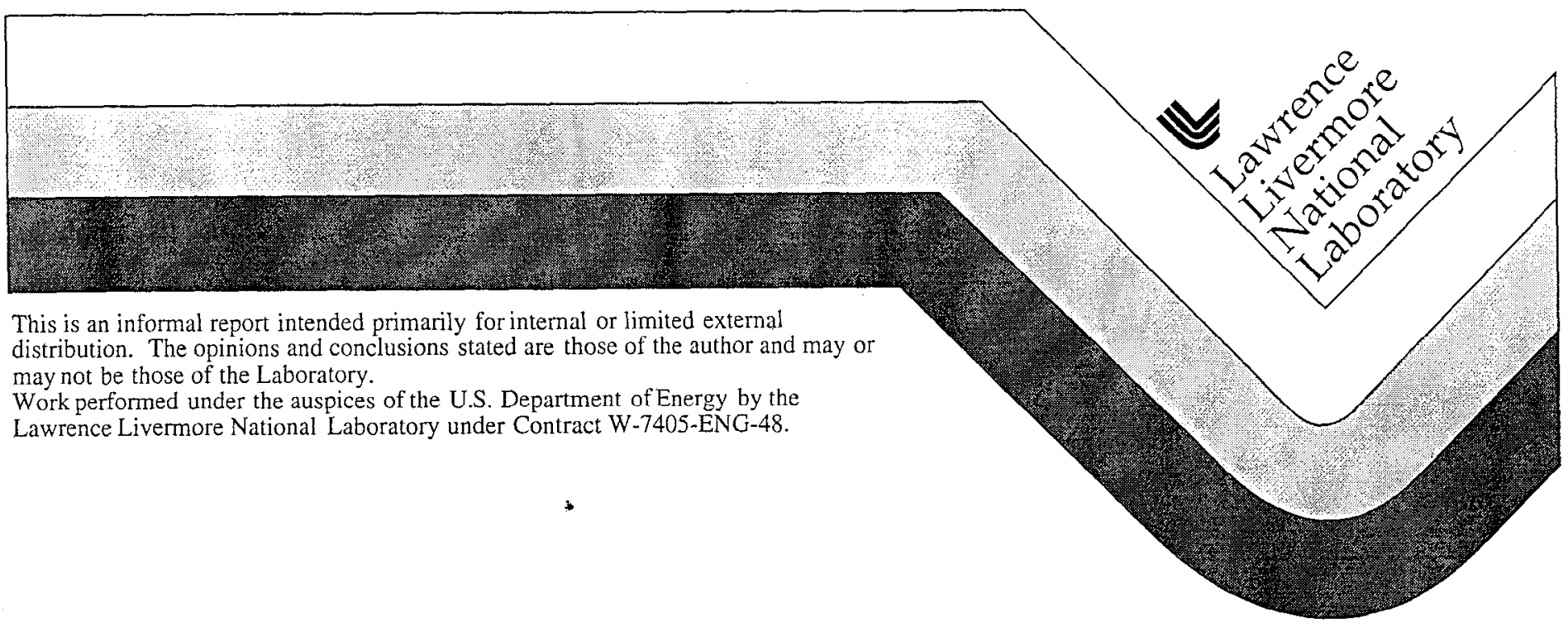




\section{DISCLAIMER}

This document was prepared as an account of work sponsored by an agency of the United States Government. Neither the United States Government nor the University of California nor any of their employees, makes any warranty, express or implied, or assumes any legal liability or responsibility for the accuracy, completeness, or usefulness of any information, apparatus, product, or process

disclosed, or represents that its use would not infringe privately owned rights. Reference herein to any specific commercial product, process, or service by trade name, trademark, manufacturer, or otherwise, does not necessarily constitute or imply its endorsement, recommendation, or favoring by the United States Government or the University of California. The views and opinions of authors expressed herein do not necessarily state or reflect those of the United States Government or the University of California, and shall not be used for advertising or product endorsement purposes. 
Tracing and Age-Dating Injected Groundwater of the West Basin Barrier Project, Los Angeles, California

\author{
M.L. Davisson, G.F. Eaton, G.B. Hudson, C. Koester \\ Lawrence Livermore National Laboratory \\ P.O. Box 808 L-231 \\ Livermore, CA 94550 \\ davisson 2@llnl.gov
}

Final Reconnaissance Report

March 26, 1999 


\section{EXECUTIVE SUMMARY}

This preliminary report summarizes results from isotopic data recently generated on water collected for the West Basin Municipal Water District (WBMWD). Samples comprised monitoring and production wells up to 3.5 miles from the injection barrier, in addition to barrier product and blend water. The preliminary conclusions based on these data include:

- As define by $\delta^{18} \mathrm{O}$ values, groundwater shows variable mixtures between pristine, local recharge and State Water Project water imported and injected into the barrier. One sample (747J) appears to be nearly $100 \%$ Colorado River water.

- Product water had a distinguishably low $\delta^{18} \mathrm{O}$ value, but blending before injection may make it relatively indistinguishable from a typical Colorado River water. $\mathrm{A} \delta \mathrm{D}$ analysis paired with the $\delta^{18} \mathrm{O}$ may help better delineate between these sources.

- Low-level MTBE measurements (detection limit = 15 parts per trillion) suggested small amounts of young water ( $<5$ yrs) were mixed in with older groundwaters.

- Groundwater ${ }^{3} \mathrm{H}^{3} \mathrm{He}$ ages ranged from 4 to 35 years old, with the oldest occurring in production wells. Ages 4 to $>20$ years were found in a monitoring wells close to the injection barrier.

- Groundwater ages generally increased with increasing distance from the injection barrier.

- Radiocarbon $\left({ }^{14} \mathrm{C}\right)$ concentrations of dissolved inorganic carbon measured in two production wells suggest recharge ages thousands of years old.

- The ${ }^{3} \mathrm{H}-{ }^{3} \mathrm{He}$ ages of groundwater suggest that horizontal transport rates range from $<100$ to $460 \mathrm{ft} / \mathrm{yr}$. Over the 2 miles of distance and 35 years of transport time suggested by the data, $>50$ percent dilution appears to have occurred. However, groundwater ages in wells near the injection barricr ( 4 to $>20$ years) do suggest flow is not uniform within the aquifer and preferred flow paths with more rapid transport rates may exist.

\section{INTRODUCTION}

The WBMWD produces 7.5 million gallons of recycled water per day utilizing lime clarification, microfiltration, and reverse osmosis technologies. Annually, 5000 acre-ft of this recycled water, or product water, is used to prevent seawater intrusion by direct injection into the West Basin Barricr Project located in southwestern Los Angeles County. 18,000 acre-ft are injected annually into the barrier, of which most comprises Metropolitan Water District imported water supplies (State Water Project and Colorado River Water).

Proposed California state regulations on treated waste water recharged into groundwater aquifers subsequently used for drinking water requires 1) at least a one year subsurface residence time, 2) a $\geq 50 \%$ dilution of recycled water by water of a non-waste 
water origin, and 3) a recycled water TOC concentration of $\leq 1.0 \mathrm{mg} / \mathrm{L}$ (State of California, 1993). Currently, product water produced by WBMWD is appropriately blended with imported water before injection. However, in the near future WBMWD would like to replace much of the imported water used for injection with recycled water, which would significantly reduce the necessary blending before injection. Consequently, WBMWD would rely on mixing in the aquifers during transport away from the injection barrier for the necessary blending.

WBMWD contracted with Lawrence Livermore National Laboratory (LLNL) to help delineate ages and mixing of groundwater in monitoring and production wells near the injection barrier. Methodologies of isotope tracing developed by LLNL have successfully demonstrated age and mixing determinations in similar water reuse projects (Hudson et al., 1995, Davisson et al., 1998). In this report, we utilize measurements of tritium $\left({ }^{3} \mathrm{H}\right)$, dissolved helium isotopes $\left({ }^{3} \mathrm{He}\right.$ and $\left.{ }^{4} \mathrm{He}\right)$, oxygen-18 $\left({ }^{18} \mathrm{O}\right)$ of the water, radiocarbon $\left({ }^{14} \mathrm{C}\right)$ of dissolved inorganic carbon, and low-level methyl-tert-butyl ether (MTBE) measurements to delineate ages and mixing for sampled wells. Detailed discussion of these research methodologies have been included in an appendix.

\section{METHODS}

A total of 13 samples were collected (see Table 1 and Fig. 1). Five samples were production wells, 5 were monitoring wells, and 3 were injection waters. The latter include product water, MWD water used for blending, and blended water in the distribution line. Sample points were distributed along the length of the injection barrier, and ranged from very near to injection points to -3.5 miles away. Samples were focused on wells completed in the Silverado Aquifer, although exact completion depths of some production wells are unknown.

Samples were collected by LLNL and WBMWD staff. Groundwater was collected directly from submersible or immersible pumps. Injection waters were collected from faucet taps. Samples for helium and other noble gases were collected in $3 / 8$ inch copper tubing by creating a laminar flow through the tube, which is connection to the pump or faucet, and crimping down on steel pinch clamps to trap an air-free water sample in the copper tube. The ${ }^{18} \mathrm{O}$ samples were collected in a $30 \mathrm{ml}$ glass bottles with an air-tight polyseal cap. Samples for ${ }^{14} \mathrm{C}$ were collected in a $125 \mathrm{ml}$ teflon-capped bottles and poisoned with a few drops of $\mathrm{HgCl}_{2}$. Samples for MTBE were collected in ultra-clean 40ml VOA vials. Trip blanks were used for the MTBE by exposing MTBE-free water in a VOA vial to the atmosphere for an amount of time equivalent to sampling. Trip blanks showed no measurable contamination.

The ${ }^{18} \mathrm{O}$ was measured with a standardized technique using the $\mathrm{CO}_{2}$ equilibration method (Epstein and Mayeda, 1953). The extraction method results in purified $\mathrm{CO}_{2}$ gas that was analyzed on a VG Prism isotope ratio mass spectrometer at LLNL. The isotope abundance is measured as a ratio to the more abundant ${ }^{16} \mathrm{O}$. This ratio is normalized to an internationally recognized standard (SMOW or Standard Mean Ocean Water) and converted to a parts per thousand scale, whereby $\delta^{18} \mathrm{O}=($ Rsample/Rstd-1) 1000 , where $\mathrm{R}$ is the ${ }^{18} \mathrm{O} /{ }^{16} \mathrm{O}$ ratio.

Tritium is analyzed by the helium-accumulation method (Surano et al., 1992), where water samples are cryogenically degassed, sealed, and stored for 15-60 days to allow 
WEST BASIN, CALIFORNIA

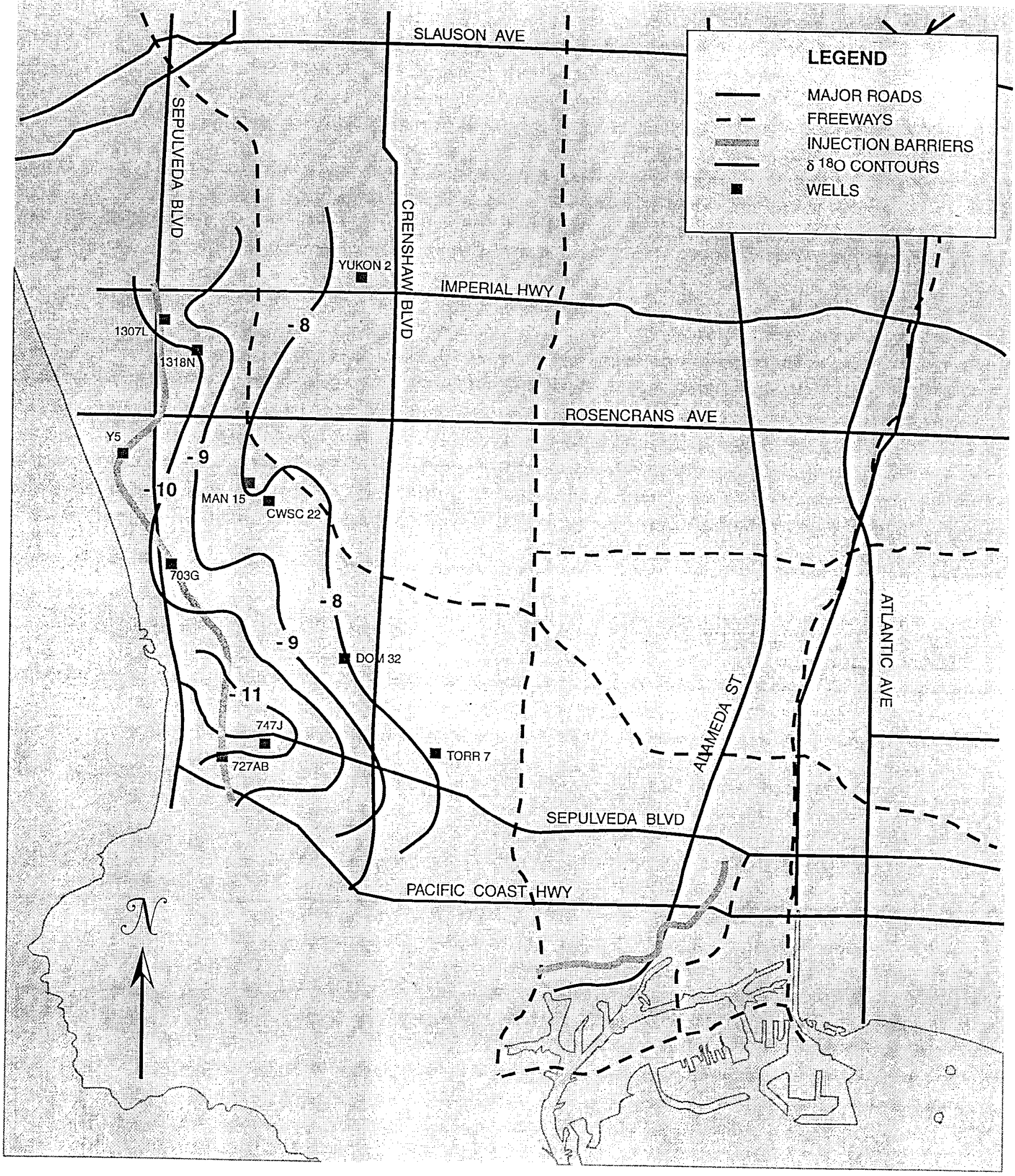

Figure 1. Well locations and $\delta 180$ contours of groundwater samples show that the $\delta 180$ values increase with increasing distance from injection barrier. 
accumulation of ${ }^{3} \mathrm{He}$ from the tritium decay. The ${ }^{3} \mathrm{He}$ is subsequently degassed, purified, and quantified on a VG-5400 noble gas mass spectrometer. The ${ }^{3} \mathrm{H}$ concentration is reported as picocuries per liter $\left(\mathrm{pCi} / \mathrm{L} ; 1.0 \mathrm{pCi} / \mathrm{L}=2 \times 104{ }^{3} \mathrm{H}\right.$ atoms $/ \mathrm{g} \mathrm{H}_{2} \mathrm{O}$ ).

The copper tubes for the dissolved noble gas measurements are vacuum fitted to an evacuated container. The copper cold seal formed during sampling is uncrimped and the water sample is released into the evacuated container where the water sample is subsequently degassed and the noble gases of interest are isolated and analyzed on a VG5400 noble gas mass spectrometer.

The MTBE was measured by purge-and-trap gas chromatography methods under ultraclean conditions, followed by ion-selective mass spectrometry.

The inorganic carbon was acid stripped under high vacuum and purged with an ultra pure carrier gas. The liberated $\mathrm{CO}_{2}$ was then reduced to graphite on a separate vacuum line using a cobalt catalyst and hydrogen gas at a $570^{\circ} \mathrm{C}$ reaction temperature. All ${ }^{14} \mathrm{C}$ concentrations were determined on the accelerator mass spectrometer at LLNL. The ${ }^{14} \mathrm{C}$ results are reported as a percent modern carbon (pmc) relative to a NBS oxalic acid standard, which represents the ${ }^{14} \mathrm{C}$ concentration of atmospheric $\mathrm{CO}_{2}$ in 1950 , before large-scale atmospheric testing of nuclear weapons commenced. Apparent ages are calculated using a half-life of 5730 ycars. The ${ }^{13} \mathrm{C} /{ }^{12} \mathrm{C}$ ratio was also determined on the dissolved inorganic carbon, and it is normalized to a standard similar to the ${ }^{18} \mathrm{O}$ and reported in $\delta^{13} \mathrm{C}$ notation.

\section{RESULTS AND DISCUSSION}

Recharge Sources

Recharge sources can be delineated using the $\delta^{18} \mathrm{O}$ measurements (see Fig. 1). Measured values range from -7.1 to -13.4 per mil. The highest $\delta^{18} \mathrm{O}$ values between -7.1 and -7.9 were measured in production wells MAN-15, Torrance-7, and SCWSYukon-2, while slightly lower values (-8.0 and -8.9 per mil) were measured in Dominguez-32 and CWSC-22. The highest value (-7.1 per mil) is consistent with values observed and expected for local precipitation recharged in coastal areas of California (Ingraham and Taylor, 1991; Williams, 1997; Davisson et al., 1998).

Injection water (Y5BB) had a significantly lower $\delta^{18} \mathrm{O}$ value $(-12.1$ per mil). This water comprised a mixture of product water ("BPW Final" in Table 1), which had the lowest $\delta^{18} \mathrm{O}$ value of -13.4 per mil, and MWD water, which was -11.3 per mil. A simple mass balance among these end-members and the blended water indicates a $38 \%$ mixture of product water in the blend. The MWD water is likely either from a Colorado River or State Water Project source. Colorado River varies in $\delta^{18} \mathrm{O}$ from approximately -13.5 to -11.0 per mil (Williams, 1997), depending on where it is sampled. Modern Colorado River usually has a high conductivity, while in the past conductivity was significantly lower. State Water Project water has a range in $\delta^{18} \mathrm{O}$ from an estimated -11.5 to -9.0 per mil. Direct measurements are scarce and this range is derived from $\delta^{18} \mathrm{O}$ values observed in the Sacramento-San Joaquin Delta, and from turnouts in San Bernadino County (unpublished data). The -11.3 per mil value for the MWD water is consistent with both 
State Water Project and Colorado River. However, the low conductivity of the MWD water suggests a State Water Project source.

The $\delta^{18} \mathrm{O}$ values in monitoring wells $(-9.3$ to -12.0 per mil) were lower than in the production wells. This indicates that the monitoring wells comprised a larger proportion of injected water compared to the production wells. Monitoring wells are located geographically closer to the injection barrier. Figure 1 and Figure 2 a show that the $\delta^{18} \mathrm{O}$ values of groundwater increase with increasing distance from the barrier, consistent with eastward transport of low $\delta^{18} \mathrm{O}$ injection water and mixing with a higher $\delta^{18} \mathrm{O}$ groundwater recharged from local precipitation. The data in Figure 2a suggests that mixing occurs primarily between a local groundwater with a -7.0 per mil value and injection water of around -11.0 per mil. The exception is in monitoring well $747 \mathrm{~J}$, which has a $\delta^{18} \mathrm{O}$ value of -12.0 per mil. Based on ${ }^{3} \mathrm{H}$ concentration and age determination, our tentative conclusion is that this groundwater is Colorado River recharge (see below). The low $\delta^{18} \mathrm{O}$ value of the product water was recently introduced into injected water, and its influence on the $\delta^{18} \mathrm{O}$ values of groundwater are clearly lacking in this data set.

Uncertainties in these interpretations are controlled by our lack of knowledge of endmember $\delta^{18} \mathrm{O}$ values. Local precipitation recharge may be variable geographically in this area, and our data is limited to just one or two analyses. In addition, the $\delta^{18} \mathrm{O}$ value of the injected water may likely vary over time, due to changing sources of imported water (i.e. Colorado River vs State Water Project). 


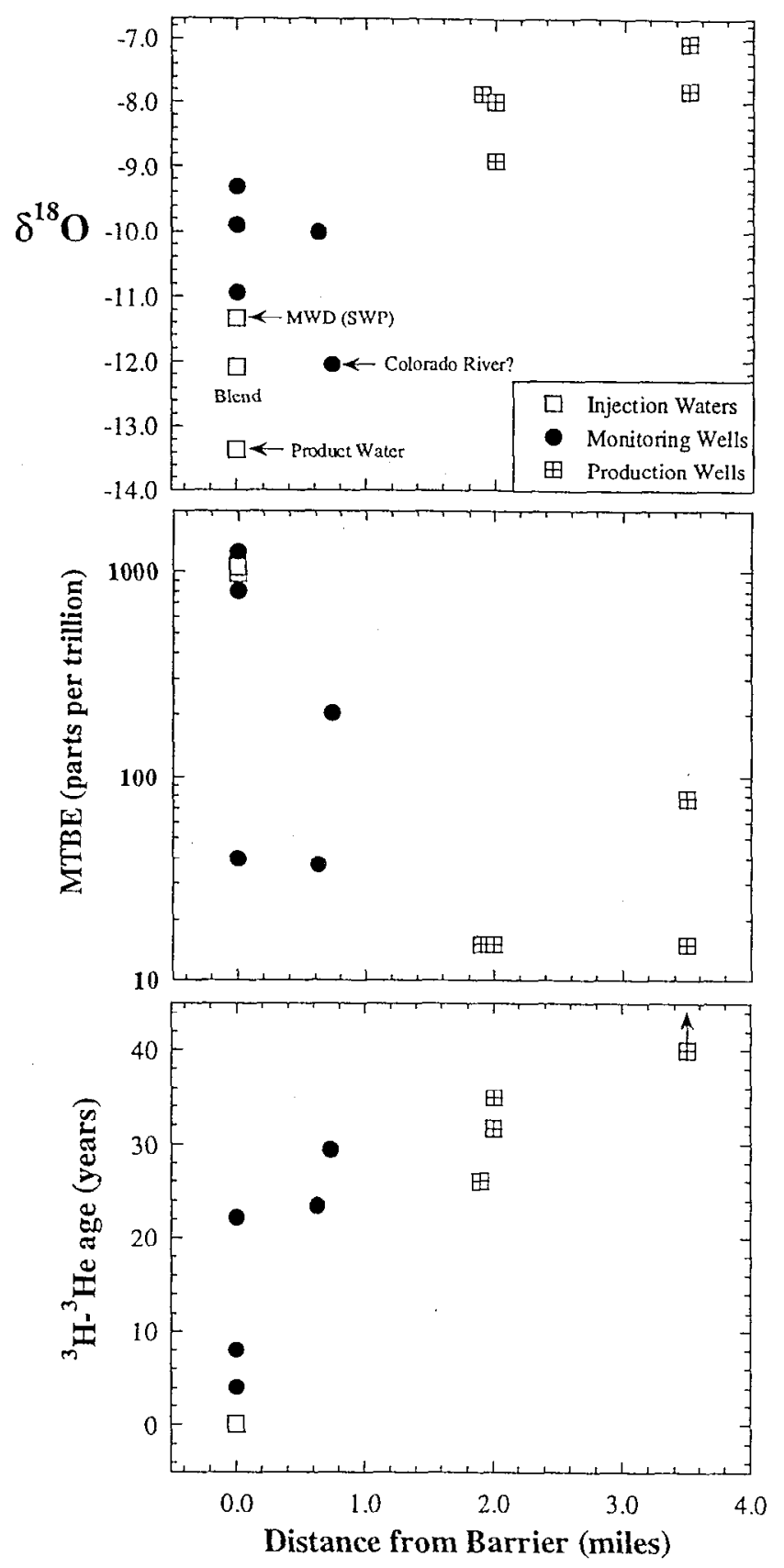

Figure 2. The $\delta^{18} \mathrm{O}, \mathrm{MTBE}$, and groundwater age all systematically vary with distance from the injection barrier. These variations are consistent with mixing between recent injection water and older groundwater derived from local precipitation.

\section{Groundwater Ages}

Tritium concentrations in the samples were variable from 0.2 to $377 \mathrm{pCi} / \mathrm{L}$. Production well SCWS-Yukon-2 had no measurable ${ }^{3} \mathrm{H}$, and well Torrance-7 only had a trace. Based on the lack of ${ }^{3} \mathrm{H}$ and ${ }^{3} \mathrm{He}$ from ${ }^{3} \mathrm{H}$ decay in these samples, these wells have groundwater ages effectively $>40$ years old. Both of these samples also had an appreciable level of dissolved ${ }^{4} \mathrm{He}$, which indicates native groundwater possibly 
thousands of years old. No other samples show elevated levels of ${ }^{4} \mathrm{He}\left(\operatorname{see}^{3} \mathrm{He} /{ }^{4} \mathrm{He}\right.$ ratios in Table 1).

All other samples had ${ }^{3} \mathrm{H}$ concentrations $>20 \mathrm{pCi} / \mathrm{L}$, suggesting a significant mixture of groundwater $<40$ years old. This includes all the other production wells. When combined with the ${ }^{3} \mathrm{He}$ measurements, calculated ages range between 4 and 35 years. These ages are "apparent ages" since groundwater samples may be mixtures of very young water and somewhat older water ( $<40$ years), which would both have ${ }^{3} \mathrm{H}$ and ${ }^{3} \mathrm{He}$. The ${ }^{3} \mathrm{H}_{-}{ }^{3} \mathrm{He}$ dating method cannot separate ages in mixed samples.

The groundwater ages generally increase with increasing distance from the injection barrier (Fig. 2c). However, groundwater sampled from monitoring wells within close proximity to the barrier (e.g. $703 \mathrm{G}, 727 \mathrm{AB}$, and 1307L) had ages from 4 to 22 years old. These older ages close to the recharge point suggest that mixing is appreciable within a few hundred feet of the barrier. Alternatively, much of the mixing could take place within the well casing due to long intervals of perforation screen.

We can calculate what the ${ }^{3} \mathrm{H}$ concentration was at the time of recharge by adding the measured ${ }^{3} \mathrm{H}$ with the measured ${ }^{3} \mathrm{He}$. In doing so, we calculate initial ${ }^{3} \mathrm{H}$ concentrations between 26 and $2049 \mathrm{pCi} / \mathrm{L}$. The latter concentration was calculated from well 747J, which we earlier interpreted as a Colorado River recharge source. The high initial ${ }^{3} \mathrm{H}$ combined with the 30 year old age is consistent with ${ }^{3} \mathrm{H}$ concentrations in precipitation accumulated in the Rocky Mountains in the late 1960s. All other initial ${ }^{3} \mathrm{H}$ concentrations are much lower (26 to $420 \mathrm{pCi} / \mathrm{L})$, and combined with their groundwater ages are consistent with ${ }^{3} \mathrm{H}$ concentrations in California precipitation.

Measurements of ${ }^{14} \mathrm{C}$ were performed on 5 samples, which include the barrier blended water, two monitoring wells (703G and $1318 \mathrm{~N}$ ), and two production wells (Dominguez32 and SCWS-Yukon-2). The production wells had the lowest ${ }^{14} \mathrm{C}$ concentrations of 47 and $53 \mathrm{pmc}$. The monitoring wells were 74 and $95 \mathrm{pmc}$, while the injection water was 75 pmc. The ${ }^{14} \mathrm{C}$ of the injection water is surprisingly low, but can be explained by low ${ }^{14} \mathrm{C}$ concentration in $\mathrm{CO}_{2}$ introduced during recarbonation of the treated waste water. The 95 pmc in one monitoring well is consistent with recent recharge ( 8 years in this case), while the 74 pmc of the other monitoring well suggests a mixture of older groundwater $(>1000$ years old). Alternatively, the inorganic carbon of injected water could have reacted with ${ }^{14} \mathrm{C}$-absent $\mathrm{CaCO}_{3}$ in the aquifer material, causing a decrease in dissolved ${ }^{14} \mathrm{C}$ concentrations of the groundwater. The low ${ }^{14} \mathrm{C}$ in production well SCWS-Yukon-2 is consistent with old recharge ( $>1000$ years old), since this sample was ${ }^{3} \mathrm{H}$-absent, suggesting no injection water has reached this well. The low ${ }^{14} \mathrm{C}$ in Dominguez-32 also suggests older recharge, but this also may be controlled by its high TDS conditions (seawater intrusion), since mineralization of ${ }^{14} \mathrm{C}$-absent organic matter is known to occur in areas of seawater intrusion (Hudson et al., 1995). Note that the ${ }^{14} \mathrm{C}$ concentration has a simple linear correlation with the dissolved inorganic carbon and the $\delta^{13} \mathrm{C}$ (see Table 1), suggesting conservative mixing between two end-members similar to the $\delta^{18} \mathrm{O}$. 


\section{Groundwater Mixing}

The $\delta^{18} \mathrm{O}$ values and ${ }^{14} \mathrm{C}$ concentrations suggest that most groundwaters are mixtures of old recharge from local precipitation with barrier injection water of more recent age. We can estimate mixing between local recharge and injected water by assuming a two end-member mixing model with $\delta^{18} \mathrm{O}$ values of -7.1 per mil for local recharge and -11.3 for injected water. The percent of injected water in a groundwater would follow the equation

$$
\text { Percent injected water }=100 \times\left(\frac{\delta^{18} O_{\text {mix }}-\delta^{18} O_{L}}{\delta^{18} O_{I}-\delta^{18} O_{L}}\right)
$$

where subscripts mix, $I$, and $L$ are respectively the measured value, the injection water (11.3 per mil), and the local recharge value $(-7.1$ per mil). Below are the calculated mixtures. Product water, the blended water, and $747 \mathrm{~J}$ are not included because their sources are unrelated. Note that production wells have the lowest mixture of injected water. The confidence in these mixtures is not high due to the limited data.

Nevertheless, these preliminary results suggest that $>50 \%$ dilution of injected water occurs before reaching production wells.

$\begin{array}{lr}\text { Injection Waters } & \text { Percent Injected Water } \\ \text { MWD-1 } & \text { imported water } \\ \text { BPW FINAL } & 100 \% \text { recycled } \\ \text { Y5BB } & \text { blend water }\end{array}$

\section{Monitoring Wells}

$703 \mathrm{G}$

$1318 \mathrm{~N}$

$727 \mathrm{AB}$

$747 \mathrm{~J}$

$1307 \mathrm{~L}$
53

69

91

67

\section{9}

17

21

0

43

Additional evidence for mixing can be gleaned from the MTBE measurements. MTBE has been used as a gasoline additive since 1996 and comprises $11 \%$ by volume all domestic gasoline consumed. Recent observations of water supplies throughout California have noted low-levels of MTBE (1-5 parts per billion). Our measuring techniques allows us to measure down to 15 parts per trillion. At these low levels, the MTBE may provide an indicator of recent groundwater recharge (e.g. $<5$ years old) mixing in small proportions with older groundwater. In addition, we expect to see an 
inverse correlation between MTBE concentration and groundwater age, due to recent increase use of MTBE. In figure 3 below, MTBE mcasured in the water samples for this study show a general inverse correlation with age. Note the 4 groundwater samples with ${ }^{3} \mathrm{H}-{ }^{3} \mathrm{He}$ ages $>20$ years old that have measurable MTBE. Assuming this MTBE is related to recent sources (injected water, leaking underground fuel tanks, etc.), the data would suggest that small amounts of recent recharge with MTBE contamination mixes in with some of the older groundwater. The mixtures are small enough that they are imperceptible with respect to the $\delta^{18} \mathrm{O}$ data. However, some uncertainty still exists as to whether older MTBE sources (before 1996) may be present in the subsurface of this area.

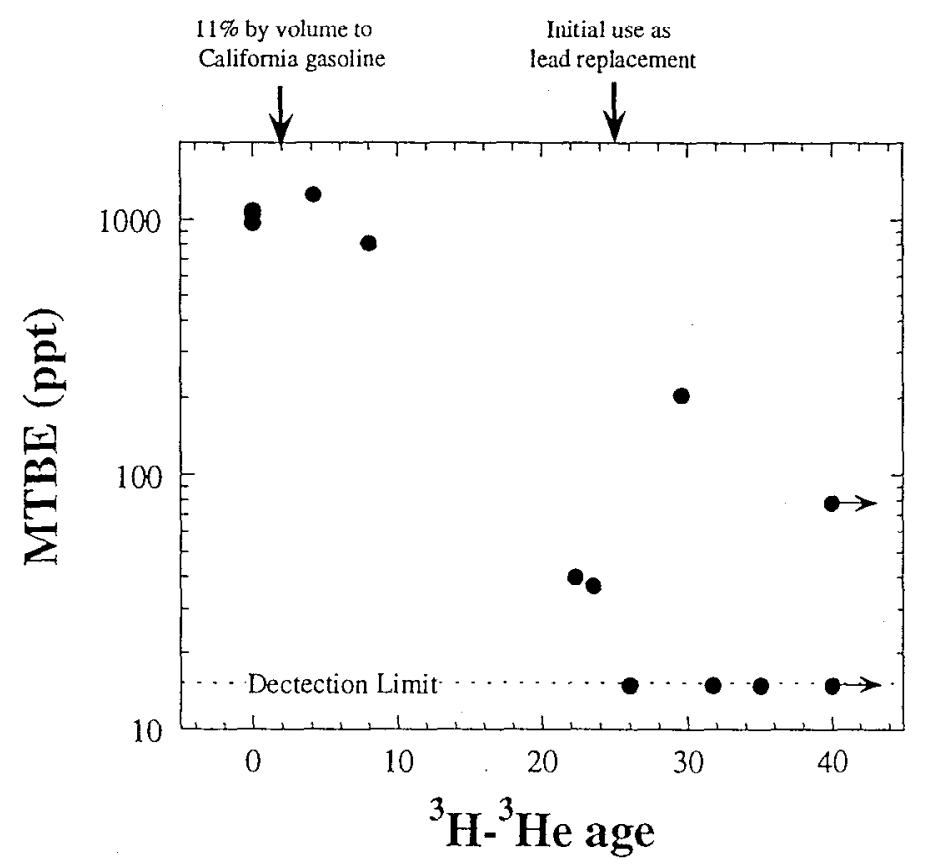

Figure 3. The MTBE shows an inverse correlation with groundwater age, reflecting recent increase use of MTBE. However, note that 4 groundwaters with ages $>20$ years have measurable amounts of MTBE, suggesting small mixtures of young ( $<5$ years) groundwater.

\section{Groundwater Transport Rates}

We can derive groundwater velocities from the ${ }^{3} \mathrm{H}-{ }^{3} \mathrm{He}$ age data. By simply dividing the groundwater age into the distance of the well from the injection barrier, we derive the linear velocity of the groundwater. Since the ages are "apparent ages", it follows that the velocities are also "apparent" transport rates. The velocities may comprise a mixture of fast and slow flow paths, corresponding to high permeability and low permeability zones in the aquifer. Below are listed calculated velocities. 


\begin{tabular}{lr} 
Monitoring Wells & feet/year \\
\hline $703 \mathrm{G}$ & $<100$ \\
$1318 \mathrm{~N}$ & 140 \\
$727 \mathrm{AB}$ & $<100$ \\
$747 \mathrm{~J}$ & 130 \\
$1307 \mathrm{~L}$ & $<100$
\end{tabular}

Production Wells

MAN-15 390

TORRANCE $7 \quad 460$

DOMINGUEZ $32 \quad 330$

SCWS-YUKON $2 \quad 460$

CWSC 22

The results suggest a range in linear velocities of at least a factor of five. Similar transport rates were calculated for the Talbert Gap injection barrier in Orange County (Hudson et al., 1995). Exact distances of monitoring wells 703G, 727AB, and 1307L were not known at the time this report was written. Therefore, $<100 \mathrm{ft} / \mathrm{yr}$ is a best estimate.

\section{CONCLUSIONS AND RECOMMENDATIONS}

Sources of groundwater recharge can be delineated with $\delta^{18} \mathrm{O}$ measurements. However, blended product water has a $\delta^{18} \mathrm{O}$ value that overlaps Colorado River values and will not be easily distinguishable. Analysis of the deuterium in water samples may provide an added tracer that will help further delineate blended product water from Colorado River water and State Water Project water. The higher $\delta^{18} \mathrm{O}$ value of local recharge derived from precipitation is easily distinguishable from injected water.

The local recharge also has an old age (>1000 years old) as distinguished by $10{ }^{14} \mathrm{C}$ concentrations and appreciably little ${ }^{3} \mathrm{H}$ and radiogenic ${ }^{3} \mathrm{He}$. Injected water ranged from 4 to 35 years old, with increased age correlating with increasing distance from the injection barrier. Lateral transport rates calculated from the ages suggest $<100$ to 460 $\mathrm{ft} / \mathrm{yr}$. Mixing is also important, and based on a $\delta^{18} \mathrm{O}$ mixing model, injection water mixed in production well water is $>50 \%$ diluted with old groundwater recharged from local precipitation.

The low-level MTBE analysis indicates that at least one production may have a small mixture of young groundwater ( $<5$ years old). All the monitoring wells had measurable MTBE levels, suggesting mixing of young water. Further delineation of young groundwater mixtures in wells, particular groundwater $<1$ year old, is difficult with the existing data. It is recommended that introduction of an artificial tracer, such as an isotopically enrich Xe, into the injection water would provide definitive proof of groundwater $<1$ year old in key wells. 


\section{REFERENCES}

Davisson, M.L., Hudson, G.B., Moran, J.E., Niemeyer, S., Herndon, R., 1998, Isotope tracer approaches for characterizing artificial recharge and demonstrating regulatory compliance. Annual UC Water Reuse Research Conference, Monterey Calif., May, 1998. 7 pp.

Epstein S., Mayeda T., 1953, Variation of ${ }^{18} \mathrm{O}$ content of waters from natural sources. Geochimica et Cosmochimica Acta 4, pp. 213-224.

Hudson G.B., Davisson M.L., Velsko C.A., Niemeyer S., Esser B.K., Beiriger J., 1995, Preliminary report on isotope abundance measurements in groundwater samples from the Talbert Gap injection barrier area, Orange County Water District. Lawrence Livermore National Lab UCRL-ID-122450, 26 pp.

Ingraham, N.L., Taylor, B.E., Light stable isotope systematics of large-scale hydrologic regimes in California and Nevada, Water Resour. Res., 27, 77-90, 1991.

State of California, 1993, Draft criteria for groundwater recharge of wastewater reclamation. Department of Health Services.

Surano, KA., Hudson, G.B., Failor, R.A., Sims, J.M., Holland, R.C., MacLean, S.C., Garrison, J.C., 1992, Helium-3 mass spectrometry for low -level tritium analysis of environmental samples. Jour. Radioanal. Nuclear Chem. Art., 161, p. 443-453.

Williams, A.E., 1997, Stable isotope tracers: natural and anthropogenic recharge, Orange County, California. Journal of Hydrology, 201, 230-248. 


\begin{tabular}{|c|c|c|c|c|c|c|c|c|c|c|c|}
\hline \multicolumn{3}{|c|}{ WEST BASIN MUNICIPAL WATER DISTRICT, LA: ISOTOPES } & & & & & & & & & \\
\hline \multirow{2}{*}{\multicolumn{2}{|c|}{$\begin{array}{l}\cdots \text { no measurement } \\
N D=\text { No Detect }\end{array}$}} & & & & - & & & & & & \\
\hline & & & & & - - - & $-{ }^{-}-{ }_{-}-$ & & & & & \\
\hline \multicolumn{3}{|c|}{$\mathrm{MW}=$ Monitoring well, $\mathrm{PD}=$ Production well, $\mathrm{SW}=$ Surface water } & & & & $\ldots$ &.- & - & & & \\
\hline & & & & & & & & & & & \\
\hline \multicolumn{2}{|c|}{ FIELD MEÁSUR̄EMENTS } & FIELD DATA & & & & $-\cdots$ & $-\cdots$ & & & & \\
\hline \multirow[t]{2}{*}{ SAMPLE } & DATE & WELL TYPE, INFO & DEPTH & PERF. & Water Level & COND. & $\mathbf{P h}$ & T WATER & $D O_{W B}$ & $\mathrm{DO}_{\text {LLNL }}$ & $\mathrm{Cl}_{2}$ \\
\hline & & & (FEET) & (FEET) & (FEET) & $(\mu \mathrm{S})$ & & $\left({ }^{\circ} \mathrm{C}\right)$ & $(\mathrm{mg} / \mathrm{L})$ & (mg/L) & $(\mathrm{mg} / \mathrm{L})_{\text {total }}$ \\
\hline \multirow[t]{2}{*}{$703 \mathrm{G}$} & $06 / 01 / 98$ & MW, El Segundo Blvd. & 384 & $250-360$ & 88 & 800.0 & 7.70 & 23.1 & 1.7 & $<1.0$ & 0.16 \\
\hline & & groundwater, Silverado aq. & & & & & & & & -1.04 & \\
\hline & & & & & & & & & & & \\
\hline \multirow[t]{3}{*}{$1318 \mathrm{~N}$} & $06 / 01 / 98$ & MW, El Segundo maintenance yard & 262 & $34-104$ & 78.6 & 1100.0 & 7.64 & 25.0 & 2.1 & 2.00 & 0.12 \\
\hline & & groundwater, Silverado aq. & & & & & & & & & \\
\hline & & & & & & & & & & & \\
\hline \multirow[t]{3}{*}{ MWD-1 } & $06 / 01 / 98$ & SW, EI Segundo maintenace yard & --- & -.. & $-\cdots$ & 400.0 & 7.95 & 25.0 & 7.00 & 8.00 & 1.11 \\
\hline & & municipal water & & & & & & & & & \\
\hline & & & & & & & & & & & \\
\hline \multirow[t]{3}{*}{ BPW FINAL } & $06 / 02 / 98$ & SW, WB Recclamation plant & $\cdots$ & $\cdots$ & $\cdots$ & 380.0 & 8.28 & 22.8 & $-\cdots$ & $\cdots$ & $\cdots$ \\
\hline & & barrier product water & & & & & & & & & \\
\hline & & & & & & & & & & & \\
\hline \multirow[t]{3}{*}{ Y5BB } & 06/02/98 & SW, Manhattan Beach & $\cdots$ & $-\cdots$ & $\cdots$ & 600.0 & 7.80 & 20.8 & 7.2 & 8.00 & $\cdots$ \\
\hline & & barrier blend & & 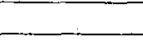 & & & & & & & \\
\hline & & & & & & & & & & & \\
\hline \multirow[t]{2}{*}{ MAN 15} & $06 / 02 / 98$ & $P W_{1}$ & $\cdots$ & $\cdots$ & --- & 920.0 & 7.44 & 22.7. & 2.7 & 1.00 & $\ldots$ \\
\hline & & Silverado aq. & & & & & & & & & \\
\hline & & & & & & & & & & & \\
\hline \multirow[t]{3}{*}{ TORRANCE 7} & $06 / 02 / 98$ & PW, Torrance, $\mathrm{H}_{2} \mathrm{~S}$ present & $\cdots$ & --- & $\cdots$ & 830.0 & 7.99 & 25.1 & 1.8 & $<1.0$ & -- \\
\hline & & groundwater, Silverado aq. & & & & & & & & & \\
\hline & & & & & & & & & & & \\
\hline \multirow[t]{2}{*}{$727 A B$} & $06 / 08 / 98$ & $\mathrm{MW}, \mathrm{H}_{2} \mathrm{~S}$ present & 375 & & 84.6 & 500.0 & 7.85 & 25.0 & 1.70 & $\cdots$ & 1.43 \\
\hline & & & - - - - & -. - & - & $-\cdots-1$ & - & -1 & & - & \\
\hline \multirow[t]{2}{*}{$747 \mathrm{~J}$} & $06 / 08 / 98$ & $\overline{M W}$ & 466 & & 73 & 500.0 & 7.63 & 22.2 & 1.9 & $\cdots$ & 0.78 \\
\hline & & & & & & & & & & & \\
\hline \multirow{3}{*}{$1307 \mathrm{~L}$} & & & & & & & & & & & \\
\hline & $06 / 11 / 98$ & MW & 252 & & 103.7 & 600.0 & 7.63 & 19.1 & 2.0 & $\cdots$ & 0.62 \\
\hline & & & & & & & -- & - & $-\ldots \ldots$ & _ & —- \\
\hline \multirow[t]{2}{*}{ DOMINGUEZ 32} & $06 / 11 / 98$ & PW, desalter influent & $-\cdots$ & $\cdots$ & $--\cdot$ & 6500.0 & 7.54 & 25.0 & 0.9 & -- & 0.94 \\
\hline & & & & & & & & & $-\cdot-$ & & \\
\hline \multirow{4}{*}{ SCWS-YUKON 2} & & & & & & & & & -. & & \\
\hline & $06 / 10 / 98$ & PW & $\cdots$ & $\cdots$ & $\cdots$ & 800.0 & 7.79 & 23.5 & 2.40 & -..- & 0.61 \\
\hline & & & & & & & & - & - & $-\ldots$ & - \\
\hline & & & & & & & & & 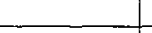 & & \\
\hline CWSC 22 & $06 / 10 / 98$ & $\mathrm{PW}, \mathrm{H}_{2} \mathrm{~S}$ present & -- & $\cdots$ & $\cdots$ & 1000.0 & 7.60 & 22.6 & 1.5 & $\cdots$ & 1.45 \\
\hline
\end{tabular}




\begin{tabular}{|c|c|c|c|c|c|c|c|c|c|c|}
\hline WEST BASIN MU & IPAL WA] & & & & & & & & & \\
\hline$\cdots$ no measuremer & & & & & & & & & & \\
\hline $\mathrm{ND}=$ No Defect & & & & & & & & & & \\
\hline MW = Monitoring & $P D=$ Pro & & & & & & & & & \\
\hline & & & & & & & & & & \\
\hline FIELD MEASURE & NTS & & & ISOTOPES & & & & & & \\
\hline SAMPLE & DATE & ${ }^{3} \mathrm{H}$ & ${ }^{3} \mathrm{H}-{ }^{3} \mathrm{He}$ age & ${ }^{14} \mathrm{C}$ & APP. AGE & $\delta^{13} \mathrm{C}_{\text {pab }}$ & DIC & $\delta^{18} \mathrm{O}_{\text {smow }}$ & ${ }^{3} \mathrm{H} /{ }^{4} \mathrm{He}$ & MTBE \\
\hline & & $(\mathrm{pCi} / \mathrm{L})$ & (years) & $(\mathrm{pmc})$ & (years) & $(\%)$ & $\left.(\mathrm{ppm} \mathrm{HCO})_{3}\right)$ & (\%) & & ppt \\
\hline $703 \mathrm{G}$ & $06 / 01 / 98$ & 23.0 & 8 & 94.9 & 431 & -9.16 & 138.30 & -9.32 & 1.13 & 807 \\
\hline & & & & & & & & & & \\
\hline & & & & & & & & & & \\
\hline $1318 \mathrm{~N}$ & $06 / 01 / 98$ & 108.0 & 24 & 73.7 & 2522 & -13.64 & 188.00 & -10.01 & 3.79 & 37 \\
\hline & & & & & & & & & —. & - \\
\hline MWD-1 & $06 / 01 / 98$ & & - & & & -6.62 & 127.10 & -11.33 & 1.00 & 974 \\
\hline & & & & & & & & & 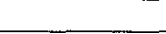 & \\
\hline & & & & & & & & & & \\
\hline BPW FINAL & $06 / 02 / 98$ & 25.7 & - & & & -30.17 & 94.60 & -13.37 & 1.01 & 1080 \\
\hline & & & & & & & & & & \\
\hline & & & & & & & & & & \\
\hline Y5BB & $06 / 02 / 98$ & 26.0 & - & 74.9 & 2391 & -11.58 & 120.10 & -12.08 & 1.00 & 1050 \\
\hline & & & & & & & & & & \\
\hline MAN 15 & $06 / 02 / 98$ & 20.0 & 26 & & & -17.94 & 282.50 & -7.88 & 1.41 & $<15$ \\
\hline & & & & & & & & & & \\
\hline & & & & & & & & & & \\
\hline TORRANCE 7 & $06 / 02 / 98$ & 1.9 & $>40$ & & $\ldots$ & -9.42 & 365.70 & -7.82 & 0.47 & 78 \\
\hline & & & & & & & & & & \\
\hline & & & & & & & & & & \\
\hline $727 \mathrm{AB}$ & $06 / 08 / 98$ & 29.0 & 4 & & & -10.93 & 128.00 & -10.94 & 1.09 & 1260 \\
\hline & & & & & & & & & & \\
\hline & & & & & & & & & & \\
\hline $747 \mathrm{~J}$ & $06 / 08 / 98$ & 377.0 & 30 & & & -10.60 & 174.90 & -12.04 & 18.00 & 204 \\
\hline & & & & & & & & & & \\
\hline $1307 \mathrm{~L}$ & $06 / 11 / 98$ & 72.0 & 22 & & & -11.50 & 170.70 & -9.90 & 2.99 & 40 \\
\hline & & & & & & & & & & \\
\hline DOMINGUEZ 32 & $06 / 11 / 98$ & 68.0 & 32 & 47.1 & 6230 & -17.26 & 210.80 & -7.99 & 3.58 & $<15$ \\
\hline & & & & & & & & & & \\
\hline & & & & & & & & & & \\
\hline SCWS-YUKON 2 & $06 / 10 / 98$ & 0.2 & $\geq 40$ & 53.0 & 5253 & -17.94 & 260.40 & -7.07 & 0.82 & $<15$ \\
\hline & & & & & & & & & & \\
\hline & & & & & & & & & & \\
\hline CWSC 22 & $06 / 10 / 98$ & 37.0 & 35 & & & -15.13 & 234.90 & -8.91 & 3.09 & $<15$ \\
\hline
\end{tabular}

